IRSTI 34.03 .21

${ }^{1 *}$ A.Y. Sikhymbayev, ${ }^{2}$ N.K. Aralbay, ${ }^{3}$ S.M. Sikhimbayeva, ${ }^{1}$ R.U. Mamykova, ${ }^{1}$ T.A. Zhgitekov, ${ }^{1}$ B.E. Narbota

${ }^{1}$ Silkway International University, Shymkent, Kazakhstan ${ }^{2}$ Kazakh Research Institute of Horticulture, Almaty, Kazakhstan ${ }^{3}$ M. Auezov South Kazakhstan State University, Shymkent, Kazakhstan *e-mail: amirbek.sikimbay@gmail.com

\title{
Current state of natural ecosystems of Western Tanirtau (Tien Shan) and taxonomical structures of the region's dendroflora
}

\begin{abstract}
Special reports on the Western Tanirtau dendroflora are currently absent. The essence of the floristic analysis given in this paper is identification of taxonomical structure of the Western Tanirtau dendroflora at the level of superfamily groups, families and genera. The objectives of the study are identification of the current state of natural ecosystems in the region. The study of the Western Tanirtau dendroflora was conducted from 2008 to 2017. The study was conducted in the region of the Kazakh part of the Western Tanirtau in the south of Kazakhstan. Collection and processing of materials was carried out by the method of A.K. Skvortsov. All species of hardy-shrub plants observed on all mountain altitudinal belts, including ranges, gorges and anthropogenically-urbanized ecosystems were recorded. During the analysis of the materials collected in the Western Tanirtau territory and review of previously collected materials identified 396 taxa of dendroflora belonging to 130 genera and 50 families. The proposed material is actual reflection of the current state of the Western Tanirtau dendroflora within Kazakhstan and for the first time a floristic spectrum of hardy-shrub plants was developed at the modern level of taxonomy and nomenclature. For the first time, the most complete list of the Western Tanirtau dendroflora, numbering 396 species of the hardy-shrub plants, is given. The data of the conducted researches testify that the Western Tanirtau dendroflora is a large center for enrichment of the genofond of plants in Kazakhstan. The complete list of the species is recommended for use in the compilation of the Plant Identifier in the vicinity of Shymkent city, as well as in the theoretical analysis of the Western Tanirtau flora. In addition, the results of the study are proposed for use in the development of resource and environmental activities in the region.
\end{abstract}

Key words: floristic spectrum, dendroflora, Western Tien Shan, flora, Kazakhstan.

\section{Introduction}

Development of scientific foundations for the optimal and sustainable use of natural resources and effective conservation of nature is impossible without multi-vector study of the plant world, as the plant world is the basic and functional basis for the existence of the biosphere, both on planetary and regional scales [1-5]. In this regard, the study of phytobiota, including in-depth floristic studies of individual natural regions and individual groups of plants, is very important. Concerning the issues of bioresources, it is necessary to emphasize the imperishable importance of dendroflora in the composition of the general flora of a particular region.

The mountain vegetation of Central Asia and Kazakhstan has attracted the attention of many sci- entists, therefore it is no accident that many works are devoted to the history of mountain forests and their genesis [6-9]. Almost all researchers recognize that the modern forests of Central Asia and southern Kazakhstan are the result of the successive development of tertiary vegetation and represent "depleted forest refugium" [6;10]. M.G.Popov [6] expressed a complete and demonstrative idea of the decisive role of the process of xerophilization of tertiary vegetation and transformation of subtropical forests of the Ginkgo flora into xerophilic forests of the Ancient Middle-earth, which resulted in the formation of wild fruit plants, including apple tree. According to his concept, subtropical forests in the Neogene have experienced three stages of transformation into xerophilic forests: walnut, oak, juniper-pistachio [11]. 
According to its plant diversity among the mountain systems of Central Asia the Tien Shan takes a special place. In the works of such scientists as Kamelin R.V. [5], Berg L.S. [12] the Tien Shan is divided into three parts: western, central (internal) and northern.

The natural conditions of the Western Tanirtau are described in great detail in the works of V.N. Pavlov [13]. In the geographical nomenclature, onomastics and toponomy of modern sovereign Kazakhstan, the original name Tanirtau is used instead of the term Tien Shan [3]. In the first works of P.P. Semenov, later P.P. Semenov-Tianshansky, called these mountains "the heavenly range" [14].

The Western Tanirtau is one of the most interesting, original and distinctive regions of Kazakhstan. The peculiarity and originality of the region is predetermined by the following factors:

- the Western Tanirtau is the richest floristic mountain ecosystem of Kazakhstan [15], here bioclimatic zones from deserts to glaciers are represented in all diversity;

- the generic flora coefficient of the Western Tanirtau is the highest in Kazakhstan and reaches $4.12[5 ; 13]$. At the same time this indicates a high degree of autonomy and originality of the Western Tanirtau flora.

- the Western Tanirtau is located in the middle of the Central Asian center of origin of cultivated plants [16], therefore it is ancient center of civilization.

One of the main characteristics of flora are spectra of floras, which express the main features of systematic composition, as well as botanical-geographical patterns $[3 ; 4]$.

The floristic spectrum of the Western Tanirtau dendroflora is compiled according to the system of A.L. Takhtadzhyan [1;2], which formed the basis of the concept of the second edition of "Flora of Kazakhstan" [3]. This work does not give the characteristics of the entire Western Tanirtau dendroflora within Kazakhstan.

There are no special reports on the Western Tanirtau dendroflora. Scientific data and characteristics of the regional hardy-shrub plant species are given in Flora and reports of Kazakhstan and Central Asia as a whole $[7 ; 8 ; 16-23]$.

Floristically, the most studied area is Aksu-Zhabagly Reserve with 1312 species [24]. Taking into account flora of western spurs of Talas Alatau, 1491 species are known (which constitute $28 \%$ of the flora of the vascular plants of Kazakhstan) [25]. Recently, for the South-Western Tien Shan (part of Uzbekistan) Tadjibayev K.Sh. described 2056 species [26].

Int. j. biol. chem. (Online)
Kamelin R.V. [5] determined about 1500 plant species for the Mashat Mountains.

According to the data of V.N. Pavlov, the entire flora of the Western Tanirtau has 2844 species [13]. If proceed from this figure, then the dendroflora of the Kazakh part of the Western Tanirtau is $13.92 \%$ of the entire Western Tanirtau flora, i.e. in the flora of the region, each "seventh" species is represented by the life form of trees, shrubs and semishrubs, and according to C. Raunkier's system - phanerophytes and chamephytes [27]. According to Ye.P. Korovin $[7 ; 8]$, the dendroflora of the whole Central Asia has 500 species. Thus, the Western Tanirtau dendroflora represents $79.20 \%$ of the total species composition of the hardy-shrub plants in Central Asia, which characterizes the region as one of the most significant and important centers of the rich diversity of the phytogenofond of Central Asia, as well as Kazakhstan.

The flora of Kazakhstan for the Western Tanirtau comprises more than 2700 species, from 587 genera, from 118 families [17]. The first report for the dendroflora of Kazakhstan gives for the region under the study 729 species, from 145 genera, from 46 families [28; 29]. In 1993-1999, the flora of the Kazygurt Mountain was studied $[30 ; 31]$, the results of which provided significant data on the Western Tanirtau dendroflora. In addition, N. Aralbay [3] supplemented these data in the compilation of the State Cadaster of Plants of the South Kazakhstan Region.

The analysis of the flora is based on a program of floristic studies of varying degrees of activity [4].

Due to the study and analysis of the urban flora of Shymkent city, information on the Western Tanirtau dendroflora was supplemented with completely new data [32].

But nevertheless, in these studies, the Western Tanirtau dendroflora within Kazakhstan was not thoroughly studied. This served as the basis for determining the current state of the natural ecosystem and taxonomical structure of the dendroflora.

The essence of our floristic analysis is identification of taxonomical structure of the flora at the level of superfamily groups, families and genera (floristic, family and generic spectra). Identification of these parameters is necessary for assessing the flora's identity and developing a scheme for floristic zoning [33].

The object of the study is the species composition of the hardy-shrub plants collected and noted in all natural, anthropogenically-urbanized ecosystems of the Western Tanirtau.

The objectives of the study are identification of the current state of natural ecosystems in the region; inventory of the species composition of the Western 
Tanirtau dendroflora; compilation of floristic spectrum of the dendroflora; determination of its position in the Western Tien Shan system of the AfghanTurkestan province.

The area of the study is characterized by the following parameters:

Relief. The Western Tanirtau includes a number of mountain ranges, which are part of the Tanitrau Mountains system. The axial range of this part is the Talas Alatau up to $74^{\circ} 30^{\backslash}$ of the east longitude $[13 ; 14]$; it also has the highest altitude (the Manas Mountains, $4882 \mathrm{~m}$ ). The most western low part of the range is called the Mashat Mountains. The spurs of the southern slope of the range bear parallel to each other, forming as a whole the angle, open to the west - the "western corner" of M.G. Popov [6]. The most western position is occupied by the Karzhantau Range, further to the east are Ugam, Pskem (with the eastern Koksu spur), Chatkal with Kuramin and Mogoltau, Atoinak and Uzunakhmat ranges.
The Western Tanirtau territory has complex relief, in which powerful mountain ranges alternate with deep intermountain valleys. Geomorphologically, the entire complex system of the Western Tanirtau ranges is grandiose branching structure on the western end of the Talas Alatau, forming a single geoblock - arched block massive [13; 14; 34; 35].

The Karzhantau range stretches from the northeast to the south-west (Figure 1). With its northern part, it joins with Ugam, forming at the junction Sairam plexus of mountains (Sairam peak - 4227 $\mathrm{m})$. The northern part of the range is the highest, the range falls to the south-west and has height of about $2000 \mathrm{~m}$ in the middle, flattened leveled ridge and low gradient soft slopes. On the southern segment, the ranges rise again (near Mynbulak peak to $2840 \mathrm{~m}$ ), the ridge in this part of the range is rocky, the slopes are steep and stony. The total length of the range is about $80 \mathrm{~km}[13 ; 14]$.

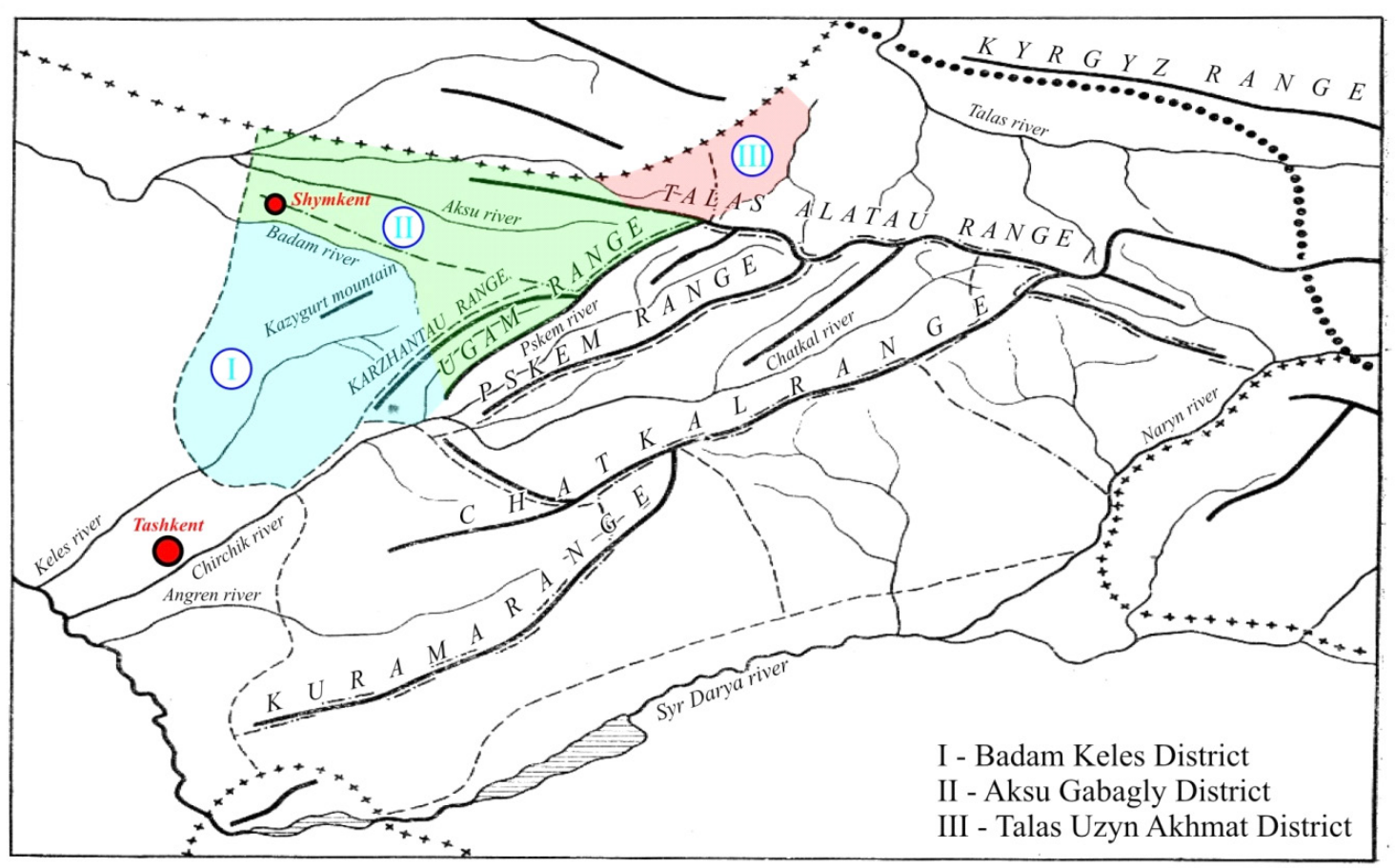

Figure 1 - Schematic map of the Western Tanirtau

The higher Ugam Range stretches to the east of Karzhantau. The southern edge of the range for about $10 \mathrm{~km}$ is relatively low $(900-1100 \mathrm{~m})$ and flat, the soft slopes are now mostly plowed. Further to the north-east, the ridge of the range increases rather sharply and at a great extent in the middle part its height is not lower than $2800-3000 \mathrm{~m}$, and separate

Int. j. biol. chem. (Online) peaks are even higher - 3504 (the Tepar Mountain), 3627, 3729 and $3812 \mathrm{~m}$ (the Ayutyur Mountain). In its middle part, the Ugam Range is asymmetric - the north-west slope is flat, the south-east - steep and more stony $[13 ; 14]$.

The height of the snow line in the Western Tanirtau varied between $3450-4000 \mathrm{~m}$. There is a regular 
increase in the snow line from the west to the east from the periphery into the depths of the mountain ridges. Despite the great absolute heights of the snow line, the snow banks persist on the northern slopes (2000-3000 m) until the end of June and the middle of July, and longer in the long snow years $[13 ; 14$; 35].

Climate. The climatic features of the Western Tanirtau are due to its location on the border between the moderate and subtropical climatic zones $[13 ; 14$; 36]. The dendroflora's richness is explained by the subtropical belt and location of axes of the ridges. For the subtropical belt, the air masses of temperate latitudes predominate in winter over its territory (with the exception of cases of separate northern occurrences), in summer - tropical masses. However, in mountainous conditions these common climatic features are transformed under the influence of relief and other local causes. The most important direction of the axes of the mountain ridges in relation to the winds of the western quarter of the horizon, which is due to penetration of moist air masses deep into the system and precipitations on the slopes. In general, the climate is sharply continental [13; 14]. It is expressed in relatively large fluctuating amplitudes of air temperature, both winter and summer, and day and night. The absolute maximum reaches $+35 \div 38^{\circ} \mathrm{C}$, and the minimum $(-25) \div(-29)^{\circ} \mathrm{C}$. The average annual air temperature varies between $9 \div 11^{\circ} \mathrm{C}$. As noted by some authors $[13 ; 14 ; 37 ; 38]$, the atmospheric circulation, expressed in the cyclonic activity of the West Asian (Iranian) branch of the polar front, plays important role in the seasonal heat distribution in the Western Tanirtau [13]. The above cyclonic activity also determines the amount of precipitation and its seasonal distribution. On average, in the study area, the average annual rainfall rises with the spring minimum of cyclonic activity in Central Asia $[13 ; 14 ; 38]$.

There are differences in climatic parameters (air temperature, amount of precipitation, soil moisture, etc.) on the slopes of the northern and southern exposures. Thus, the slopes of the north-western exposition are most moistened in comparison with the south-eastern ones. In general, the Western Tanirtau is characterized by climatic heterogeneity. Increased solar radiation, contrast of temperatures, irregular precipitation and local phenomena of atmospheric circulation create conditions for variegated mosaic of vegetation cover $[13 ; 14]$.

The annual heat balance in the Western Tanirtau territory is approaching $45-50 \mathrm{kcal} / \mathrm{cm}^{2}$ [39]. The highest values were recorded at altitudes of up to $1200 \mathrm{~m}$, higher they naturally decrease.

Int. j. biol. chem. (Online)
Typical for all mountainous Central Asia, the climatic continentality in the Western Tanirtau is expressed in high summer temperature peaks, observed to high altitudes. The absolute maximum of the lowest part $\left(-41.2^{\circ} \mathrm{C}\right)$ differs from the known maxima of high points $\left(+32.4^{\circ} \mathrm{C}\right)$ by less than $10^{\circ} \mathrm{C}$ $[13 ; 14]$.

The atmospheric circulation plays important role in seasonal heat distribution. The Western Tanirtau is located in the cyclonic zone of the West Asian (Iranian) branch of the air front [38]. Due to the presence of ridges of latitudinal strike, which protect it from the invasion of the European cold masses, the Western Tanirtau is characterized by mild winters. The average temperature in January in Pskem, Chimgan is not lower than $-5^{\circ} \mathrm{C}$, which is only $2-4^{\circ} \mathrm{C}$ less than in the same months in Tashkent and Shymkent, although the difference in the heights of these places reaches $1300 \mathrm{~m}[13 ; 14]$.

The cyclonic activity determines the amount and seasonal distribution of precipitation. The annual precipitation amounts in various parts of it fluctuate within considerable limits: from 134 to $996 \mathrm{~mm}$. The amount of precipitation naturally increases with the ascent, while the rate of increase by $100 \mathrm{~m}$ varies with altitude on the slopes of different ridges and in different areas $[13 ; 14]$.

For the Western Tanitau, a long period of summer drought is associated with the annual minimum of precipitation. As the ascent increases, the duration of the dry period decreases. The annual amounts of precipitation change regularly from the west to the east $[13 ; 14 ; 40]$.

In the Western Tanirtau, differences in climatic indices in the northern and southern exposures are clearly evident. Especially significant is difference in soil moisture regime at different exposures and slopes. On the southern slopes, a considerable part of the moisture is lost due to rapid melting of the snow (partially evaporating), since in the spring melt waters form solifluction streams and rapid ground water runoff $[13 ; 14 ; 41 ; 42]$. In general, it is possible to speak about significant climatic heterogeneity of the Western Tanirtau. This explains diversity of vegetation cover, including dendroflora. If culture of some subtropical plants is possible in the southern and western parts when watering [43], even tomatoes do not ripen in the upper part of the mountain valleys $[13 ; 14]$.

Soil cover. As noted by V.N. Pavlov [13; 14], in the mountains the most important factors of soil formation are, on the one hand, altitude zonality and, on the other hand, exposure of slopes, emphasizing 
that these phenomena are of different order and they cannot be countered.

According to V.N. Pavlov [13; 14], the main vertical belt spectrum of soils of the Western Tanirtau is as follows:

I. Low mountains - ordinary (typical) and dark gray soils (in the upper part mountain gray-brown, ordinary soils and dark gray dry steppe - on the slopes of the northern exposures);

II. Middle mountains - light and dark-brown (black-brown) soils, brown and dark brown (blackbrown), in some places (under spruce-fir forests) mountain dark-colored forest;

III. Uplands - mountain light-brown, meadowsteppe, brown, chernozem soils under subalpine meadows and meadow-steppes, mountain meadow sod semi-peaty leached, mountain sod-brown dry steppe $[6 ; 13]$.

It should be noted that many studies by other researchers have been devoted to the belt distribution of the Western Tanirtau $[5 ; 7-9 ; 44]$. In the most modern work $[31 ; 45]$, the authors, using the classification of K.Z. Zakirov [46], offer the following classification of soil and vegetation belts of the Western Tanirtau:

Shol (Chul). Foothills and low mountains (500$800 \mathrm{~m}$, sometimes up to $1300 \mathrm{~m}$ ). Ephemeral desert steppes, grass-sagebrush deserts, gypsophilous shrubs and semi-shrubs are characteristic for this type of vegetation. The climate is very hot, extra-arid. The soils are gray soils, in some places low-carbonate gray soils.

Adyr. The type of vegetation in the interval 800 (1300)-1700 m of absolute altitude. The main dominants of this belt are grasses and a variety of dry grass (semi-savannas), as they move upwards they are replaced by xerophilous shrubs and trees (shiblyak, badal). The climate is arid and subarid. The soils are light brown, rank and stony.

Tau. The type of vegetation, characteristic of absolute altitude of $1700-2800 \mathrm{~m}$. From the phytocenotic point of view, this belt is very rich and diverse. This belt is characterized by all the unique features of the Western Tanirtau. Steppe groups, subarid, humid, petrophilic groups, mesophilic walnut forests, mixed forests, juniper stands and spruce, conifer forests, mesophilous shrubs, meadows and meadow grounds, petrophilous cenoses, etc. are found nearby. The upper boundary of this belt is characterized by subalpine and alpine meadows. The climate is subhumid (in the lower part) and humid. The soils are brown and rank or rank dark brown.

Zhailau (yailau). The vegetative type of the zone is 2800-3400 (above 3500) $\mathrm{m}$ of absolute height. The

Int. j. biol. chem. (Online) main type of vegetation is alpine meadows. The climate is cryophilic-humid. The soils are cryohydromorphic, in the nival belt - low-power and incompletely-formed.

In this paper, we recognize the chorologic rank of the Western Tanirtau as a phytogeographical province. And the internal division into districts take according to V.N. Pavlov [13; 14].

According to V.N. Pavlov $[13 ; 14]$, in the natural boundaries of the Western Tanirtau, nine districts are naturally and clearly distinguished according to the complex natural and climatic characteristics: I - Aksu-Zhabagly; II - Talas-Uzunakhmat; III Badam-Keles; IV - Upper Chirchik; V - Parkent; VI - Santalash-Chatkal; VII - Aflatun-Karasu; VIII - Kuraminsk; IX - South Chatkal.

The Kazakh part of the Western Tanirtau is represented within the Aksu-Zhabagly, Talas-Uzunakhmat (partially) and Badam-Keles districts. Therefore, during the floristic analysis of the Western Tanirtau dendroflora, we studied only in these three districts (Figure 1).

\section{Materials and methods}

The study of the Western Tanirtau dendroflora was carried out by us in different seasons with numerous field visits conducted during the period from 2008 to 2017 . The basis of the study was the outline of the Western Tanirtau dendroflora [47]. Collection and processing of material for the present work was carried out according to the generally accepted method of A.K. Skvortsov [48].

All species of hardy-shrub plants observed on all mountain altitudinal belts, including ranges, gorges and agrocenoses, anthropophytons were recorded. The studies were carried out by the route-reconnaissance method.

The study was conducted in the region of the Kazakh part of the Western Tanirtau in the south of Kazakhstan $\left(68^{\circ}\right.$ of the north latitude, $42^{\circ}$ of the east longitude), where the flora stretches over a vast area, about 13200-13800 $\mathrm{km}^{2}$ (selected areas I, II and III in Figure 1).

The floristic analysis of the dendroflora was carried out on the basis of the ecology-system approach, theoretical aspects of which in Kazakhstan for the last 20-30 years are widely reflected in the works [4953]. 396 taxa of the dendroflora have been identified during the identification of materials collected during the expedition in the Western Tanirtau territory, as well as viewing of previously collected material stored in the Herbarium of the Institute of Botany and 
Phyto-Introduction of the Ministry of Education and Science of the Republic of Kazakhstan, the Institute of the Genetic Fund of Flora and Fauna of the Academy of Sciences of the Republic of Uzbekistan.

\section{Results and discussion}

396 species of hardy-shrub plants from 130 genera and 50 families, presented in Table 1, were recorded within the Kazakh part of the Western Tanir-

Table 1 - Floristic spectrum of the Western Tanirtau dendroflora

\begin{tabular}{|c|c|c|}
\hline Tax & Genera & Species \\
\hline \multicolumn{3}{|c|}{ Section MAGNOLIOPHYTA } \\
\hline \multicolumn{3}{|c|}{ Group MAGNOLIOPSIDA } \\
\hline \multicolumn{3}{|c|}{ Subclass A. Magnoliidae: } \\
\hline \multirow[t]{2}{*}{ Magnoliaceae } & 2 & 2 \\
\hline & 2 & 2 \\
\hline \multicolumn{3}{|c|}{ Subclass B. Ranunculiidae } \\
\hline Berberidaceae & 1 & 7 \\
\hline \multirow[t]{2}{*}{ Ranunculaceae } & 2 & 6 \\
\hline & 3 & 13 \\
\hline \multicolumn{3}{|c|}{ Subclass C. Caryophyllidae: } \\
\hline Chenopodiaceae & 2 & 2 \\
\hline Polygonaceae & 2 & 9 \\
\hline \multirow[t]{2}{*}{\begin{tabular}{|l|} 
Limoniaceae \\
\end{tabular}} & 1 & 2 \\
\hline & 5 & 13 \\
\hline \multicolumn{3}{|c|}{ Subclass D. Hamamelididae: } \\
\hline Platanaceae & 1 & 1 \\
\hline Fagaceae & 2 & 7 \\
\hline Betulaceae & 3 & 8 \\
\hline \multirow[t]{2}{*}{\begin{tabular}{|l} 
Juglandaceae \\
\end{tabular}} & 3 & 6 \\
\hline & 9 & 22 \\
\hline \multicolumn{3}{|c|}{ Subclass E. Dilleniidae } \\
\hline Tamaricaceae & 2 & 7 \\
\hline Salicaceae & 2 & 23 \\
\hline Capparaceae & 1 & 1 \\
\hline Ebenaceae & 1 & 1 \\
\hline Brassicaceae & 1 & 1 \\
\hline Tiliaceae & 1 & 4 \\
\hline Malvaceae & 1 & 1 \\
\hline Ulmaceae & 2 & 8 \\
\hline Celtidaceae & 1 & 5 \\
\hline \multirow[t]{2}{*}{ Moraceae } & 4 & 1 \\
\hline & 16 & 52 \\
\hline \multicolumn{3}{|c|}{ Subclass F. Rosidae } \\
\hline Saxifragaceae & 1 & 2 \\
\hline Grossulariaceae & 2 & 7 \\
\hline Rosaceae & 21 & 106 \\
\hline Fabaceae & 17 & 31 \\
\hline Sapindaceae & 1 & 1 \\
\hline
\end{tabular}

Int. j. biol. chem. (Online) tau, based on the study of herbarium funds in Almaty, Shymkent (Kazakhstan), Tashkent (Uzbekistan), literature data and own research.

It should be noted that 205 species from of 396, or $51.76 \%$ of them are characteristic of oases, agrophytocenoses, urbanized ecosystems, altered under the influence of anthropogenic impact, i.e. for anthropophyton. The floristic spectrum was compiled according to the system of A.L. Takhtadzhyan [1;2], taking into account the latest nomenclatural changes [23].

\begin{tabular}{|c|c|c|}
\hline Aceraceae & 1 & 12 \\
\hline Hippocastanaceae & 1 & 2 \\
\hline Rutaceae & 1 & 1 \\
\hline Simarubaceae & 1 & 1 \\
\hline Anacardiaceae & 3 & 5 \\
\hline Celastraceae & 1 & 5 \\
\hline Rhamnaceae & 3 & 4 \\
\hline Eleagnaceae & 2 & 4 \\
\hline Vitaceae & 2 & 5 \\
\hline Punicaceae & 1 & 1 \\
\hline Cornaceae & 2 & 5 \\
\hline Araliaceae & 1 & 1 \\
\hline Caprifoliaceae & 2 & 18 \\
\hline Viburnaceae & 1 & 2 \\
\hline \multirow[t]{2}{*}{ Sambucaceae } & 1 & 2 \\
\hline & 65 & 215 \\
\hline \multicolumn{3}{|c|}{ Subclass G. Lamiidae } \\
\hline Rubiaceae & 2 & 3 \\
\hline Oleaceae & 5 & 15 \\
\hline Solanaceae & 2 & 3 \\
\hline Bignoniaceae & 1 & 3 \\
\hline \multirow[t]{2}{*}{ Lamiaceae } & 7 & 22 \\
\hline & 17 & 46 \\
\hline \multicolumn{3}{|c|}{ Subclass H. Asteridae } \\
\hline \multirow[t]{2}{*}{ Asteraceae } & 5 & 11 \\
\hline & 5 & 11 \\
\hline Total: & 122 & 374 \\
\hline \multicolumn{3}{|l|}{ Section Pynophyta } \\
\hline \multicolumn{3}{|l|}{ Group Gnetopsida } \\
\hline \multirow[t]{2}{*}{ Ephedraceae } & 1 & 3 \\
\hline & 1 & 3 \\
\hline \multicolumn{3}{|c|}{ Group Ginkgoopsida } \\
\hline \multirow[t]{2}{*}{ Ginkgoaceae } & 1 & 1 \\
\hline & 1 & 1 \\
\hline \multicolumn{3}{|l|}{ Group Pinopsida } \\
\hline Pinaceae & 3 & 8 \\
\hline \multirow[t]{2}{*}{ Cupressaceae } & 3 & 10 \\
\hline & 6 & 18 \\
\hline Total: & 8 & 22 \\
\hline Total: 50 families & 130 & 396 \\
\hline
\end{tabular}


This floristic spectrum shows the main features of the systematic structure of the Western Tanirtau dendroflora, which is expressed in the following: the dendroflora is represented by representatives of only two divisions of the plant world, while the entire regional flora consists of representatives of five plant sections.

According to our results, almost 95\% (94.44\%) of the dendroflora species composition are represented by taxa of Magnoliophyta section, i.e. flowering plants, the distinctive feature of the floristic spectrum is the fact that all Magnoliophyta are in their entirety and completely representatives of the group Magnoliopsida - dicotyledons. There is no one representative of Liliopsida, monocotyledons, even in cultural cenoses - anthropophyton they are not recorded. In classical florogenetic analyzes the ratio of dicotyledons and monocotyledon is important botanical-geographical indicator. Thus, in the regional flora of the Western Tanirtau $[13 ; 14]$, the ratio of dicotyledons and monocotyledons is 4.4:1. For comparison - a similar ratio in Zaisan hollow is 4.5:1 [49].

In general, such ratio of dicotyledons and monocotyledons is characteristic of the territory of the eastern part of the Ancient Middle-earth [9]. Complete absence of monocotyledons in the formation of the Western Tanirtau dendroflora indicates that, mainly, the dendroflora consists of boreal, moderately warm species. In more detail, this can be traced by considering the ratio of the large systematic groups of the flora under the study (Table 2).

Table 2 - Ratio of the main systematic groups of the Western Tanirtau dendroflora

\begin{tabular}{|c|c|c|c|c|}
\hline \multirow{2}{*}{ Systematic groups } & \multicolumn{3}{|c|}{ Amount of } & \multirow{2}{*}{$\begin{array}{c}\text { from the total number } \\
\text { of species }\end{array}$} \\
\cline { 2 - 5 } & families & genera & species & 5.55 \\
\hline I. Pynophyta & 4 & 8 & 3 & 0.75 \\
\hline Gnetopsida & 1 & 1 & 1 & 0.25 \\
\hline Ginkgoopsida & 1 & 1 & 18 & 4.54 \\
\hline Pinopsida & 2 & 6 & 374 & 94.44 \\
\hline II. Magnoliophyta & 46 & 122 & 374 & 0.44 \\
\hline Magnoliopsida & 46 & 122 & 2 & 3.28 \\
\hline Magnoliidae & 1 & 2 & 13 & 3.28 \\
\hline Ranunculiidae & 2 & 3 & 22 & 5.55 \\
\hline Caryophyllidae & 3 & 5 & 52 & 13.13 \\
\hline Hamamelididae & 4 & 9 & 215 & 54.29 \\
\hline Dilleniidae & 10 & 16 & 46 & 11.61 \\
\hline Rosidae & 20 & 65 & 11 & 2.77 \\
\hline Lamiideae & 5 & 17 & 396 & 100 \\
\hline Asteriidae & 1 & 5 & & \\
\hline Total: & 50 & 130 & & \\
\hline
\end{tabular}

As can be seen, from the Table 2, gymnosperms in the Western Tanirtau dendroflora are represented by only 22 species and compose weakly noticeable share of only $5.55 \%$. From Magnoliophyta, a large number of species are concentrated in the subclasses of, Dilleniales, Lamiales and Hamamelinaceous, in each of which there are 1-2, rarely more families, abundant genera and species. It should be emphasized that among the major subclasses is Rosidae, which exceeds according to the number of species other subclasses by 5-9 times. More than half of the species of the Western Tanirtau dendroflora are concentrated in this subclass. This gives grounds for confident assumption that many large families and genera of the Western Tanirtau dendroflora will be in this subclass. This also indicates that the dendroflora formation history can be largely related to the phylogeny of families and genera of Rosales of Rosidae subclass.

The species diversity of Salicaceae, Lamiaceae, Caprifoliaceae, Oleaceae exceeds the average from 2 to 3 times (Figure 2). 


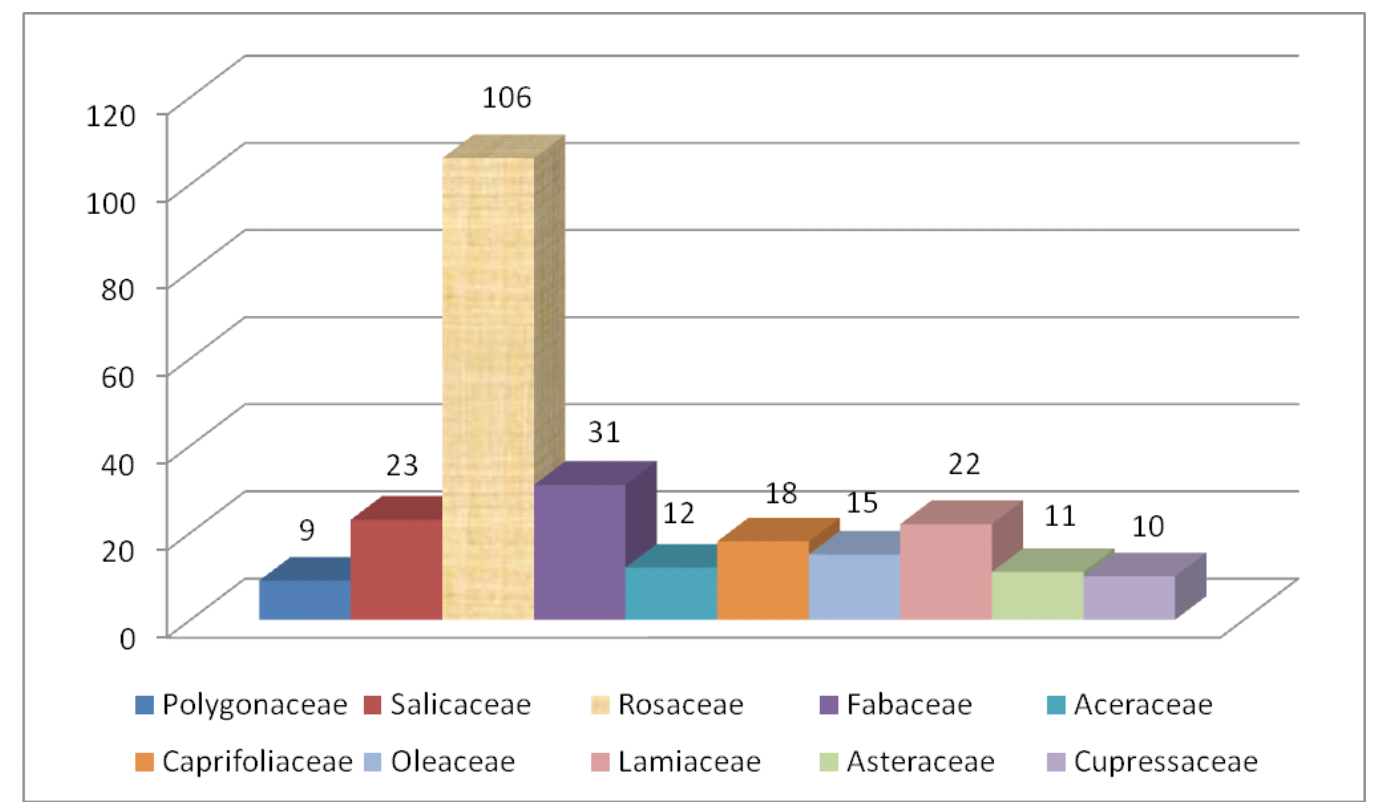

Figure 2 - Spectrum of the leading families of the Western Tanirtau dendroflora

The average level of species diversity of the Western Tanirtau dendroflora families is 7.92 , or on average for each family there are almost 8 species. The average level of species diversity is 2.60 , i.e. on average for each family there are about 3 genera.

From 10 leading families, 4 - Rosaceae, Fabaceae, Caprifoliaceae, and Aceraceae, represent the subclass Rosidae. They contain 167 species or $42.5 \%$ of the species composition of the regional dendroflora. Hyperpolymorphous family of the Western Tanirtau dendroflora is Rosaceae, the species diversity of which exceeds the average level by more than 13 times. A very polymorphous family is Fabaceae, species diversity of which exceeds the average level by a little more than 3 times.

A special feature of the species diversity of $\mathrm{Ro}$ saceae family plants is that from 106 species 51 (48.1\%) are represented by anthropophyton - agrocenoses, cultural landscapes, urbanized ecosystems and oases. The species composition of such genera as Malus, Crataegus, Cerasus, and Sorbus in the Western Tanirtau dendroflora exceeds the species composition of these genera in the natural flora of Kazakhstan by 1.1-3.7 times, eg. Malus by 3.7 times, Crataegus by 1.2 times, Cerasus by 1.1 times, Sorbus by 1.75 times. The aforementioned species composition is primarily represented by fruit-bearing and beautifully flowering trees and shrubs, the majority of species belongs to Anthropophyton.

The species composition of such genera as Acer, Berberis, Quercus, Ulmus and Fraxinus in the West- ern Tanirtau dendroflora exceeds the species composition of these genera in the natural flora of Kazakhstan by 1.1-6.5 times, eg. Acer by 6.5 times, Berberis by 1.1 times, Quercus by 6 times, Ulmus by 3 times, Fraxinus by 3 times.

This allows to make affirmative conclusion about the enrichment of phytogenous fund of the Western Tanirtau and Kazakhstan as a whole. The data of the conducted research testifies that the Western Tanirtau dendroflora is a large center for enrichment of the gene fund of Kazakhstani plants.

\section{Conclusion}

The proposed material is actual reflection of the current state of the Western Tanirtau dendroflora within Kazakhstan. For the first time the floristic spectrum of hardy-shrub plants was developed by us at the modern level of taxonomy and nomenclature. For the first time, the most complete list of the Western Tanirtau dendroflora, numbering 396 species of the hardy-shrub plants, belonging to 130 genera and 50 families, is given. The data presented in the paper is recommended for use in the preparation of the Kazakhstan National Strategy for Conservation and Balanced Use of Biological Diversity, and under discussion for inclusion in the "Plant Identifier of the Republic of Kazakhstan". The complete list of the species is recommended for use in the compilation of the Plant Identifier in the vicinity of Shymkent city, as well as in the theoretical analysis of the Western 
Tanirtau flora. In addition, the results of the study are proposed for use in the development of resource and environmental activities in the region.

\section{Acknowledgment}

The authors are grateful to the staff of the Institute of Botany and Phyto-Introduction of the Ministry of Education and Science of the Republic of Kazakhstan, the Institute of the Genetic Fund of Flora and Fauna of the Academy of Sciences of the Republic of Uzbekistan, represented by Professors U.P. Pratov and K.Sh. Tozhibayev, whose materials were used in the preparation of the paper.

\section{References}

1. Tahtadzhjan A.L. (1970) Proishozhdenie i rasselenie cvetkovyh rastenij. Leningrad: Nauka, p. 145.

2. Tahtadzhjan A.L. (1987) Sistema magnoliofitov. Leningrad: Nauka, p. 439.

3. Aralbaj N.K. (2016) Koncepcija jenciklopedicheskogo spravochnika «Қазақstannyң flora-sy». Ust'-Kamenogorsk: Izd-vo «Media-Al'jans», p. 104.

4. Jurceva B.A. (1987) Teoreticheskie i metodicheskie problemy sravnitel'noj floristiki. Leningrad: Nauka, p. 296.

5. Kamelin R.V. (1973) Florogeneticheskij analiz estestvennoj flory gornoj Srednej Azii. Lenin-grad: Nauka, p. 356.

6. Popov M.G. (1940) Rastitel'nyj pokrov Kazahstana. Trudi Kazakhskoi Akademiî nauk Fil-iala Akademii nauk SSSR, vol.18, p. 216.

7. Korovin E.P. (1961) Rastitel'nost' Srednej Azii i Juzhnogo Kazahstana. Tashkent: Izda-tel'stvo Akademii nauk Uzbekskoj SSR, vol. 1, p. 452.

8. Korovin E.P. (1962) Rastitel'nost' Srednej Azii i Juzhnogo Kazahstana. Tashkent: Izda-tel'stvo Akademii nauk Uzbekskoj SSR, vol. 2, p. 549.

9. Kamelin R.V. (1967) O nekotoryh zamechatel'nyh anomalijah vo flore gornoj Srednej Aziatskoj provincij. Botanicheskij zhurnal, vol. 52, no. 4, pp. 447-460.

10. Dzhangaliev A.D. (1977) Dikaja jablonja Kazahstana. Almaty: Nauka, p. 284.

11. Popov M.G. (1928/1929) Dikie plodovye derev'ja i kustarniki Srednej Azii. Trudy po pri-kladnoj botanike, genetike i selekcii, vol. 22, no. 3, pp. 241-483.

12. Berg L.S. (1937) Priroda SSSR. Moscow: Geografgiz, p. 287.

13. Pavlov V.N. (1980) Rastitel'nyj pokrov Zapadnogo Tjan'-Shanja. Moscow: MGU, p. 248.

Int. j. biol. chem. (Online)
14. Semenov P.P. (1858) Pervaja poezdka na Tjan'-Shan' ili nebesnyj hrebet do verhov'ja r. JakSarta ili Syr-Dar'i dejstvitel'nogo chlena P.P. Semenova v 1857 g. s kartoju. St.-Petersburg: Vesti Imperatorckogo Russkogo Obshestva, chast' 22.

15. Bajtulin I.O. (1999) Nacional'naja strategija po sohraneniju i sbal. ispol'zovaniju BR v Ka-zahstane. Kokshetau: IntelService, p. 356.

16. Zhukovskij P.M. (1974) Kul'turnye rastenija. Zhizn' rastenij. vol. 1, pp. 162-173.

17. Pavlova N.V. (1956-1966) Flora Kazahstana. Almaty: Fylym, vol. I-IX.

18. Korovin Ye.P. (1961-1991) Opredelitel' rastenij Srednej Azii. Tashkent: FAN, , vol. I-II.

19. Illjustrirovannyj opredelitel' rastenij Kazahstana (1969-1972). Alma-Ata: Nauka, vol. 1, p. 640.

20. Illjustrirovannyj opredelitel' rastenij Kazahstana (1969-1972). Alma-Ata: Nauka, vol. 2, p. 572.

21. Aralbaev N.K., Kudabaeva G.M., Veselova P.V., Danilov M.P., Zakirova R.O., Nelina N.V., Zhamangara A.K., Nigmatova S.A., Samojlova V.A., Shadrina N.V., Muhtubaeva S.K., Kurmantaeva A. A., Isaev E.B., Sihymbaev A.E. (2002) Gosudarstvennyj kadastr rastenij Juzhno-Kazahstanskoj oblasti. Konspekt vidov vysshih sosudistyh rastenij. Almaty: NIC «Fylym», p. 314.

22. Cherepanov S.K. (1995) Sosudistye rastenija Rossii i sopredel'nyh gosudarstv (v predelah byvshego SSSR). St.-Petersburg: Mir i Sem'ja, p. 990 .

23. Stanjukovich K.V. (1973) Rastitel'nost' gor SSSR. Dushanbe: Donish, p. 416.

24. Karmysheva N.H. (1973) Flora i rastitel'nost' zapovednika Aksu-Dzhabagly. Alma-Ata: Nauka, p. 180.

25. Karmysheva N.H. (1982) Flora i rastitel'nost' zapadnyh otrogov Talasskogo Alatau. Alma-Ata: Nauka, p. 162.

26. Tozhibaev K.Sh. (2010) Flora Jugo-Zapadnogo Tjan'-Shanja (v predelah Respubliki Uzbekistan) Tashkent: FAN, p. 100.

27. Raunkiaer C. (1934) The life form plants and statistical plant geography. Oxford: Clarendon press, vol. 2, pp. 37-50.

28. Mushegjan A.M. (1962) Derev'ja i kustarniki Kazahstana. Alma-Ata: Kajnar, vol. 1, p. 364.

29. Mushegjan A.M. (1966) Derev'ja i kustarniki Kazahstana. Alma-Ata: Kajnar, vol. 2, p. 344.

30. Sikhymbayev, A.Ye. (1999) Flora of the Kazygurt Mountain. Abstract of thesis of candidate of biological sciences, Tashkent: Tashkent State University, p. 24. 
31. Sihymbaev A.E. (2012) Kazygurt tauynyn florasy (monografija). Shymkent: Nurly bejne, p. 176.

32. Sihimbaeva S.M. (2014) Shymkent kalasynyn urbanoflorasy. Shymkent: Alem, p. 184.

33. Malyshev L.I. (1987) Sovremennye podhody $\mathrm{k}$ kolichestvennomu analizu i sravneniju flor. Teoreticheskie i metodicheskie problemy sravnitel'noj floristiki: Materialy 2 rabochego soveshhanija po sravnitel'noj floristike. Leningrad: Nauka. pp. 142149.

34. Svarichevskaja Z.A. (1965) Geomorfologija Kazahstana i Srednej Azii. Leningrad: Izda-tel'stvo Leningradskogo gosudarstvennogo universiteta, p. 296.

35. Meshherjakov Ju.A. (1972) Rel'ef SSSR (morfostruktura i morfoskul'ptura). Moscow: Mysl', p. 520 .

36. Rybin N.G. (1952) Ustrojstvo poverhnosti Kazahstana. Ozera Kazahstana. Ledniki Kazah-stana. V knige: Ocherki po fizicheskoj geografii Kazahstana. Alma-Ata: Nauka, p. 512.

37. Alisov B.P. (1956) Klimat SSSR. Mocsow: Izdatel'stvo Moskovskogo gosudarstvennogo universiteta, p. 127.

38. Borisov A.A. (1970) Klimatografija Sovestkogo Sojuza. Leningrad: Izdatel'stvo Leningrad-skogo gosudarstvennogo universiteta, p. 331.

39. Ivanov N.N. (1959) Pojasa kontinental'nosti Zemnogo shara. Izvestija vsesojuznogo geo-graficheskogo obshhestva, vol. 91, no. 5, pp. 29-34.

40. Kuvshinova K.V. (1968) Klimat. V knige: Srednjaja Azija. Moscow: Nauka, p. 192.

41. Shhul'c V.L. (1949) Reki Srednej Azii. Zapadnoe Vsesoiuznoe Geograficheskoe Obshestvo. Novaja serija, vol. 8, pp. 27-35.

42. Stepanov I.N. (1975) Jekologo-geograficheskij analiz pochvennogo pokrova Srednej Azii. Moscow: Nauka, p. 168.

43. Paravjan A.V. (1960) Opyt akklimatizacii kustarnikov v gornyh uslovijah Srednej Azii. Al-ma-
Ata: Institut botaniki Akademii nauk Kazahskoj SSR, p. 266.

44. Kul'tiasov M.V. (1955) Osobennosti jekologii vysokogornyh rastenij Zapadnogo Tjan'-Shanja. Moscow: Izdatel'stvo Akademii nauk SSSR, p. 127.

45. Aralbaj N.K., Tagajbekova D.S., Isaev E.B. (2016) Batys Tjan'-Shan' osimdikter duniesinin beldeulik taralu erekshelikterine taldau. V sbornike: Atyrau Altaj arasy - Kazaktyn baj flo-rasy, Almaty: Ulagat, pp. 68-72.

46. Zakirov K.Z., Zakirov P.K. (1971) Zakonomernosti raspredelenija rastitel'nogo pokrova i principy vysotnoj zonal'nosti. V knige: Rastitel'nyj pokrov Uzbekistana. Tashkent: FAN, vol. 1, p. 155.

47. Sihymbaev A.E. (2017) Materialy k dendroflore Zapadnogo Tanirtau (monografija). Shymkent: Izdatel'stvo Juzhno-Kazahstanskogo pedagogicheskogo universiteta, p. 122.

48. Skvorcov A.K. (1977) Gerbarij. Posobie po metodike i tehnike. Moscow: Nauka, p. 198.

49. Aralbaj N.K. (2015) Flora Zajsanskoj kotloviny (monografija). Almaty: Ulagat, p. 364.

50. Bajtulin I.O. (1987) Sostojanie i perspektivy ohrany rastenij Kazahstana. Ohrana redkih vi-dov rastenij i rastitel'nosti Kazahstana. Almaty: Nauka, pp. 3-19.

51. Bajtulin I.O. (1993) Garmonizacija problem jekonomiki i jekologii v razvitii obshhestva. Izvestija Nacional'noj akademii nauk Respubliki Kazahstan. Serija Biologija, vol.1, pp. 3-8.

52. Bajtulin I.O. (1996) Sistemnyj podhod k sohraneniju i sblansirovannomu ispol'zovaniju biologicheskogoraznobrazija. Podgotovitel'nyj jetap razrabotki Nacional'noj strategii i plana dejstvij sohranenija i sbalansirovannogo ispol'zovanija biologicheskogo raznoobrazija: respublikanskij seminar. Almaty, pp. 12-23.

53. Bajtulin I.O., Kurochkina L.Ja., Aralbaev A.K. (1996) Nacional'naja programma dejstvij po bor'be s opustynivaniem v RK (rasshirennyj referat). Almaty, p. 31. 